\title{
Alloantibodies and Australia antigen after open heart surgery
}

\author{
S. D. SLATER ${ }^{1}$ \\ From the Department of Haematology, Royal Infirmary, Glasgow
}

SYNOPSIS The development of irregular serum antibodies (alloantibodies) following massive transfusion was studied in 144 patients who had undergone cardiac valve replacement. An overall incidence of alloimmunization of $8.3 \%$ was found. Of the 15 antibodies detected nine were Rhesus anti-E and four anti-Kell. The incidence of anti-E formation in Rhesus E-negative patients was $11.4 \%$; the corresponding figure for anti-Kell was $3 \cdot 2 \%$. The results suggest that the risk of alloimmunization is directly related to the volume of blood transfused, and Rhesus E-negative persons appear to be at particular risk.

Australia (Au) antigen investigations were also carried out in 102 of these cases. Three patients were $\mathrm{Au}$ antigen positive, one of them developing acute hepatitis. In each case no Au antigen could be detected in the donor blood that was used.

It is suggested that tests for alloantibodies and for the Australia antigen should become part of the routine follow -up of any patient receiving massive transfusion.

Following transfusion of $\mathrm{ABO}$ and Rhesus (D) compatible blood irregular antibodies may develop due to minor differences in blood group phenotype between donor and recipient. There have been few studies of the effect of massive transfusion on alloimmunization and results are conflicting (Wallace and Henry, 1965; Lostumbo, Holland, and Schmidt, 1966; Perkins, 1968; Polesky, Smith, and Weirich, 1969). Considerable quantities of blood are often required for open heart surgery with cardiopulmonary bypass, and this paper reports a study of the incidence of alloimmunization in patients who have undergone cardiac valve replacement.

Blood transfusion may also be responsible for the transmission of serum hepatitis. The prevalence of Australia (Au) antigen in blood donors varies according to geographical and social factors (Cossart, 1972; Maycock, 1972). It may be expected, however, that the larger the transfusion the greater the risk of infection, although not all reports record a continuously ascending risk with increasing transfusion volume (Proskey, Morrison, McQuillan, and Parker, 1970). Investigations were, therefore, also carried out for Au antigen in these patients.

${ }^{1}$ Present address and correspondence to Dr S. D. Slater, Department of Medicine, Southern General Hospital, Govan Road, Glasgow.

Received for publication 27 September 1973.

\section{Patients and Methods}

One hundred and forty-four patients with prosthetic heart valves were investigated. There were 63 men and 81 women, and they were selected at random from patients with prosthetic valves attending the anticoagulant clinics. They comprised 113 cases of single valve replacement, 29 of double valve replacement, and two of triple valve replacement. The operations had been performed two to 74 months previously although the majority were within the previous 24 months (table I). Blood used at operation was ABO and Rhesus (D) compatible.

Blood grouping with identification of Rhesus phenotype and Kell and Duffy a blood group status was carried out by standard methods. Serum was

\begin{tabular}{lc}
\hline Months after Operation & Number of Patients \\
\hline $0-3$ & 2 \\
$3-6$ & 48 \\
$6-12$ & 32 \\
$12-24$ & 36 \\
$24-36$ & 13 \\
$36-60$ & 6 \\
$60-84$ & 7 \\
& 144
\end{tabular}

Table I Timing of initial postoperative investigations 
screened for the presence of irregular antibodies by testing against a comprehensive panel of red cell antigens obtained from the Regional Blood Transfusion Service using the following techniques: (1) room temperature saline, (2) $37^{\circ} \mathrm{C}$ saline, (3) enzyme (ficin-treated test cells), and (4) antihuman globulin. The specificity of any antibody detected was then precisely identified using a panel of cells supplied by Ortho Diagnostics.

Serum was examined by the Regional Virus Laboratory for the presence of Australia antigen by immunoelectroosmophoresis and complement-fixation tests (Pringle, Ross, and McMichael, 1972).

\section{Results}

DISTRIBUTION OF BLOOD GROUP ANTIGENS In 121 cases the Rhesus phenotype and in 116 cases the Kell and Duffya blood group status were

\begin{tabular}{lrr}
\hline Antigen & + & - \\
\hline $\mathrm{C}$ & $84(69 \%)$ & $37(31 \%)$ \\
$\mathrm{c}$ & $102(84 \%)$ & $19(16 \%)$ \\
$\mathrm{D}$ & $104(86 \%)$ & $17(14 \%)$ \\
$\mathrm{E}$ & $38(31 \%)$ & $83(69 \%)$ \\
$\mathrm{e}$ & $116(96 \%)$ & $5(4 \%)$ \\
$\mathrm{K}$ & $13(11 \%)$ & $103(89 \%)$ \\
Fys & $69(59 \%)$ & $47(41 \%)$ \\
\hline
\end{tabular}

Table II Distribution of blood group antigens ${ }^{1}$

${ }^{1}$ Showing number (and $\%$ no) of patients possessing $(+)$ or lacking $(-)$ the corresponding antigen.

identified (table II). The results compare very well with published data for the incidence of these blood group antigens (Giblett, 1961; Race and Sanger, 1968), and are used to estimate the antigen status of the remaining patients in whom the full Rhesus phenotype or Kell and Duffy a group was not determined.

\begin{tabular}{|c|c|c|c|c|c|c|c|c|}
\hline \multirow[t]{2}{*}{ Case } & \multirow[t]{2}{*}{ Blood Group } & \multirow[t]{2}{*}{ Operation } & \multirow{2}{*}{$\begin{array}{l}\text { Volume of } \\
\text { Blood Used } \\
\text { (units) }\end{array}$} & \multirow{2}{*}{$\begin{array}{l}\text { Preoperative } \\
\text { Antibody } \\
\text { Screening }\end{array}$} & \multicolumn{4}{|c|}{ Postoperative Antibody Screening } \\
\hline & & & & & $\begin{array}{l}\text { Time (mth } \\
\text { post } \\
\text { operatively) }\end{array}$ & Result & Method & \\
\hline 1 & $\begin{array}{l}\text { O } \\
\text { Rhesus CóDee } \\
\text { Kell + ve Fy }(a+v e)\end{array}$ & AVR & 14 & Negative & 8 & Anti-E & Enzyme & $1: 4$ \\
\hline 2 & $\begin{array}{l}\text { O } \\
\text { Rhesus CCDee } \\
\text { Kell + ve Fy }(a-v e)\end{array}$ & MVR & & Negative & 23 & Anti-E & Enzyme & $1: 4$ \\
\hline 3 & $\begin{array}{l}\text { O } \\
\text { Rhesus CāDee } \\
\text { Kell - ve Fy }(a+v e)\end{array}$ & MVR & 6 & Negative & 23 & Anti-E & $\begin{array}{l}\text { Enzyme } \\
\text { IAHGT }\end{array}$ & $\begin{array}{l}1: 16 \\
1: 1\end{array}$ \\
\hline 4 & $\begin{array}{l}\text { A } \\
\text { Rhesus CCDee } \\
\text { Kell - ve Fy }(a+v e)\end{array}$ & AVR & 20 & Negative & 4 & Anti-E & $\begin{array}{l}\text { Enzyme } \\
\text { IAHGT }\end{array}$ & $\begin{array}{l}1: 8 \\
1: 2\end{array}$ \\
\hline 5 & $\begin{array}{l}\text { A } \\
\text { Rhesus CCDee } \\
\text { Kell - ve Fy }(\mathrm{a}+\mathrm{ve})\end{array}$ & $\begin{array}{l}\text { MVR } \\
+ \\
\text { Aortic valvotomy }\end{array}$ & 16 & Negative & 14 & Anti-E & Enzyme & $1: 8$ \\
\hline 6 & $\begin{array}{l}\text { O } \\
\text { Rhesus CōDee } \\
\text { Kell - ve Fy (a - ve) }\end{array}$ & MVR & 9 & Negative & 6 & Anti-E & Enzyme & $1: 8$ \\
\hline 7 & $\begin{array}{l}\text { O } \\
\text { Rhesus CCDee } \\
\text { Kell - ve Fy }(a-v e)\end{array}$ & $A+\mathbf{M V R}$ & 13 & Negative & $\begin{array}{l}12 \\
12\end{array}$ & $\begin{array}{l}\text { Anti-E } \\
\text { Anti- } \overline{\mathbf{c}}\end{array}$ & $\begin{array}{l}\text { Enzyme } \\
\text { IAHGT } \\
\text { Enzyme }\end{array}$ & $\begin{array}{l}1: 4 \\
1: 1 \\
1: 8\end{array}$ \\
\hline 8 & $\begin{array}{l}\text { A } \\
\text { Rhesus CčDee } \\
\text { Kell - ve Fy }(a-v e)\end{array}$ & $\begin{array}{l}\text { AVR } \\
\text { AVR } \\
\text { (repeat) }\end{array}$ & $\begin{array}{l}11 \\
16\end{array}$ & $\begin{array}{l}\text { Negative } \\
\text { Negative }\end{array}$ & $\begin{array}{r}13 \\
6\end{array}$ & $\begin{array}{l}\text { Anti-P } \\
\text { Anti-E }\end{array}$ & $\begin{array}{l}\text { Room to } \\
\text { Enzyme }\end{array}$ & $\begin{array}{r}\text { aline } \\
1: 2\end{array}$ \\
\hline 9 & $\begin{array}{l}\text { A } \\
\text { Rhesus CōDee } \\
\text { Kell - ve Fy }(a+v e)\end{array}$ & MVR & 13 & Negative & $\begin{array}{r}4 \\
28\end{array}$ & $\begin{array}{l}\text { Anti-E } \\
\text { Anti-Kell }\end{array}$ & $\begin{array}{l}\text { Enzyme } \\
\text { Enzyme } \\
\text { IAHGT }\end{array}$ & $\begin{array}{l}1: 4 \\
1: 16 \\
1: 8\end{array}$ \\
\hline 10 & $\begin{array}{l}\text { B } \\
\text { Rhesus CōDee } \\
\text { Kell - ve Fy }(a-v e)\end{array}$ & MVR & 24 & Negative & 71 & Anti-Kell & IAHGT & $1: 8$ \\
\hline 11 & $\begin{array}{l}\text { B } \\
\text { Rhesus CōDee } \\
\text { Kell - ve Fy }(\mathrm{a}+\mathrm{ve})\end{array}$ & MVR & 8 & Negative & 7 & Anti-Kell & Enzyme & $1: 2$ \\
\hline 12 & $\begin{array}{l}\text { O } \\
\text { Kesus CčDee } \\
\text { Kell vy }(a+v e)\end{array}$ & $\mathbf{A}+\mathbf{M V R}$ & & Negative & 16 & Anti-Kell & IAHGT & $1: 8$ \\
\hline
\end{tabular}

\section{Table III Details of patients with alloantibodies ${ }^{1}$}

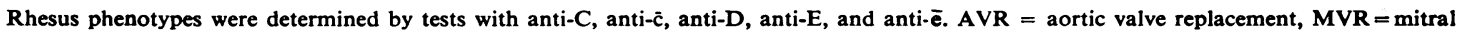
valve replacement.

ntibody screens: only the method(s) yielding positive reactions are tabulated; IAHGT = indirect antihuman globulin test. 


\begin{tabular}{|c|c|c|c|c|c|}
\hline \multirow[t]{2}{*}{ Case } & \multirow[t]{2}{*}{ Operation } & \multirow[t]{2}{*}{ Blood and Blood Products Used } & \multirow[t]{2}{*}{ Previous Transfusion } & \multicolumn{2}{|c|}{ Postoperative Australia Antigen Test } \\
\hline & & & & $\begin{array}{l}\text { Time (mth post- } \\
\text { operatively) }\end{array}$ & Result (method) \\
\hline 1 & $A+\mathbf{M V R}$ & $\begin{array}{l}13 \text { units blood } \\
2 \text { units FFP } \\
4 \text { units fibrinogen }\end{array}$ & Nil & 4 & $\begin{array}{l}\text { Antigen positive } \\
\text { (IE \& CF) }\end{array}$ \\
\hline 2 & AVR & $\begin{array}{l}13 \text { units blood } \\
1 \text { unit fibrinogen } \\
10 \text { units cryoppt. }\end{array}$ & Nil & 4 & $\begin{array}{l}\text { Antigen positive } \\
\text { (IE \& CF) }\end{array}$ \\
\hline 3 & $A+M V R$ & $\begin{array}{l}11 \text { units blood } \\
1 \text { unit fibrinogen } \\
10 \text { units cryoppt. }\end{array}$ & $\begin{array}{l}4 \text { units blood } \\
12 \text { years previous } \\
\text { to } A+M V R\end{array}$ & 2 & $\begin{array}{l}\text { Antigen positive } \\
\text { (CF) }\end{array}$ \\
\hline
\end{tabular}

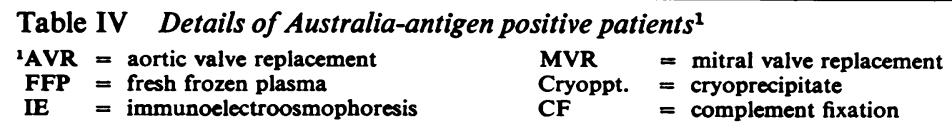

\section{ALLOANTIBODIES}

Of the 144 patients studied, $12(8.3 \%)$ developed irregular serum antibodies postoperatively (table III). In nine cases $(6.25 \%)$ Rhesus anti-E was detected. However, a more meaningful expression is to relate the incidence of anti-E to the number of $R h(E)$-negative persons potentially exposed to the $\mathrm{E}$ antigen. Excluding 16 patients who were also $R h$ (D) negative and had received only $R h$ (D)negative blood (which as supplied in this region is also Rhesus $C$ and $E$ negative), 67 were found to be $\mathrm{E}$ negative. A further 12 were estimated to be $\mathrm{E}$ negative in those patients with unknown full Rhesus phenotypes. Of this total of 79 , therefore, $11.4 \%$ had developed anti-E. Anti-Kell was detected in four patients, an incidence of $3.2 \%$ in 124 Kell-negative cases (103 known plus 21 estimated).

Antibody tests were repeated at intervals over a period of 19 to 30 months in nine of the affected patients. In seven of these detectable antibody persisted although in two (cases 4 and 11) there was an interim period when negative tests were obtained, and in one (case 7) there was persistent loss of detectable activity in respect of one (anti-c) of the two antibodies initially present. In two patients (cases 8 and 9) follow-up investigations were repeatedly negative for the antibody originally identified, but case 8 developed another antibody (anti-E) after his second aortic valve replacement, and another antibody (anti-Kell) was also detected in case 9.

In addition to the 12 patients who developed antibodies postoperatively a further four gave positive results. The antibodies identified were anti-C plus anti-D (one patient), anti-E (one patient), and unidentified antibodies (two patients). These had all, however, been detected before the valve replacement operation and so cannot be attributed to it, and the four patients were excluded from the above calculations of anti-E and anti-Kell incidence.

\section{AUSTRALIA ANTIGEN}

Investigations for Australia $(\mathrm{Au})$ antigen were also carried out in 102 of these patients. Three cases were found to be Au antigen positive, one (case 3) developing hepatitis (table IV).

\section{Discussion}

Antibodies to red cell antigens may develop following $\mathrm{ABO}$ and Rhesus (D) compatible blood transfusion since it is virtually impossible to match donor and recipient blood completely. However, the remaining blood group antigens appear to be relatively weak, and the overall incidence of alloimmunization following transfusion has been reported as approximately $1 \%$ (Grobbelaar and Smart, 1967), and is probably less with single transfusions (Giblett, 1961). Massive transfusions contain a potentially greater variety as well as a larger volume of foreign antigen, but there have been few studies of their effect on alloimmunization and results are conflicting. Wallace and Henry (1965) found alloantibodies in two of 65 open heart surgery patients (average transfusion 17 units), and concluded that massive transfusion probably does not increase the risk of alloimmunization. Perkins (1968) found that only $1.5 \%$ of 539 open heart surgery cases (average transfusion 13 units) developed clinically significant antibodies, and Polesky et al (1969) had similar results in a study of 100 postoperative cardiac surgery patients. On the other hand, Lostumbo et al (1966) detected blood group specific antibodies in $24 \%$ of 127 patients exposed to an average of 24.9 units of blood during open heart surgery. They concluded that the risk of alloimmunization is additive and approximately $1 \%$ per unit of transfused blood.

In this study, $8.3 \%$ of 144 patients developed blood-group-specific antibodies after open heart surgery. The total quantity of blood used during 
operation and in the immediate postoperative period in the affected patients varied from 6 to 24 units (mean $\pm \mathrm{SD}=13.6 \pm 5.3$ ), and similar volumes were used in the unaffected patients. Three patients had had blood transfusions of up to 4 units six to 10 years before the valve operation. One other (case 8) received a further 11 units of blood between his first and corrective second operation because of the development of haemolytic anaemia. Six patients had had one or more pregnancies between four and 24 years before operation. However, all of the affected cases had been investigated for irregular antibodies more than once preoperatively with negative results. It is most likely, therefore, that the alloantibodies detected postoperatively were a consequence of the transfusion at operation. One probable exception is the first antibody (anti- $P_{1}$ ) found in case 8 which, while not detected before his first operation, is by its nature and serological reaction unlikely to have been immune in origin (Mollison, 1967). The high incidence of alloimmunization found in this study suggests that its development may be directly related to the volume of blood used, although the interesting possibility has been raised that an extracorporeal circulation may enhance the antigenicity of donor red cells (Brown and Smith, 1958).

There are a number of possible explanations for the wide divergence of results in these studies. Wallace and Henry (1965) did not employ an enzyme-treated red cell method which is considered the most sensitive technique for detecting Rhesus antibodies (Stratton, 1953; Kissmeyer-Nielsen, 1965; Myhre, Greenwalt, and Gajewski, 1965). Lostumbo et al (1966) include several antibodies often regarded as 'naturally occurring' (Giblett, 1961; Mollison, 1967). The timing and frequency of the antibody screening procedure is also of importance, and testing only in the very early postoperative period (Polesky et al, 1969) is unlikely to detect a developing immune antibody (Pickles, M. M., cited by Mollison, 1967). In this study, antibodies initially detected in five patients were not found at subsequent screenings, although this was a temporary phenomenon in two of them. It is clear that one negative test does not exclude the possibility of alloimmunization, nor is loss of previously detectable antibody activity by in-vitro tests necessarily paralleled by a disappearance of agglutinating or haemolytic potency in vivo (Fudenberg and Allen, 1957; Chaplin and Cassell, 1962).

The antibodies most frequently developed following transfusion of $\mathrm{ABO}$ and $\mathrm{Rh}$ (D)-compatible blood are anti-Kell, anti-E, and anti-c (Levine, Robinson, Stroup, McGee, and Bushnell, 1956; Giblett, 1961; Grobbelaar and Smart, 1967). Giblett
(1961) has estimated the relative potency of an antigen by comparing it with the potency of the Kell antigen. This she has taken to be 0.05 , that is, that anti-Kell may be expected to develop in $5 \%$ of transfusions involving a Kell-positive donor and a Kell-negative recipient, and the $\mathrm{E}$ antigen was calculated to be about one-third as potent $(0.0169)$. Using Giblett's method of calculation, the results in this study suggest a figure for the relative potency of the E-antigen of 0.035 . Any comparison of estimates of antigen potency, however, must take into account possible differences in the manner, amount, and frequency of exposure to the foreign antigen. It appears likely, nonetheless, that after massive transfusion E-negative patients may be at greater risk of developing anti-E than has perhaps been realized.

It is suggested that investigations for alloantibodies should become part of the routine follow up of any patient receiving massive transfusions and these tests might usefully be done at two, six, and 12 months.

Australia $(\mathrm{Au})$ antigen investigations were carried out in $\mathbf{1 0 2}$ patients and three were found to be $\mathrm{Au}$ antigen positive. By contrast the prevalence of Australia antigen in unpaid blood donors in the USA and western Europe is about 0.1 to $0.2 \%$ (Cossart, 1972; Maycock, 1972). None of the affected cases gave a past history of jaundice or had been in known contact with jaundice for at least the previous six months, and only one had received blood or blood products before the valve operation. Two of them remain clinically well but the third developed hepatocellular jaundice eight weeks postoperatively after a two weeks' prodromal illness, and it was then that the Au antigen was detected. His illness quickly subsided and one week later tests for $\mathrm{Au}$ antigen were negative. It is of interest that a patient not in this study but sharing the same cubicle also developed an Au antigen-positive acute hepatitis after surgery. This raises the question of portal of entry for the infective agent. It is also noteworthy that in each of these Au antigen-positive cases no Au antigen could be detected in the donor blood that was used. Preoperative testing for $\mathrm{Au}$ antigen was not carried out in these affected patients and so the evidence that their subsequent detection was due to the large volume of blood or to blood products used at the time of operation can only be presumptive. Lockey, Cossart, and Gonzalez-Lavin (1973) found a similar incidence in 135 open heart surgery patients tested both pre- and postoperatively, three of their cases becoming Au antigen positive after surgery. As with alloantibody formation the number of cases of Au antigen detected may be greater if repeated investigations are performed. 
Aside from its epidemiological value, screening for $\mathrm{Au}$ antigen in patients after a valve has been replaced defines those who are potentially infectious in a group of patients likely to be on long-term anticoagulant therapy and the subjects of repeated venepuncture. It is recommended that tests for $\mathrm{Au}$ antigen should also become part of the routine follow up of patients receiving massive transfusions especially if further investigative procedures are to be carried out.

I thank Mr W. Bain, Department of Cardiac Surgery, Dr J. F. Davidson, Department of Haematology, and Dr J. Wallace, Regional Director, Blood Transfusion Service, for their help and encouragement. I am indebted to Mr R. Dick and the technical staff of the Blood Transfusion Department, Glasgow Royal Infirmary, and also to Dr Constance A. C. Ross and Mr S. McMichael of the Regional Virus Laboratory, Ruchill Hospital, Glasgow.

\section{References}

Brown, I. W., Jr., and Smith, W. W. (1958). Hematologic problems associated with the use of extracorporeal circulation for cardiovascular surgery. Ann. intern. Med., 49, 1035-1048.

Chaplin, H., Jr., and Cassell, M. (1962). The occasional fallibility of in-vitro compatibility tests. Transfusion (Philad.), 2, 375-384.

Cossart, Y. E. (1972). Epidemiology of serum hepatitis. Brit. med. Bull., 28, 156-162.

Fudenberg, H. H., and Allen, F. H., Jr. (1957). Transfusion reactions in the absence of demonstrable incompatibility. New Engl. J. Med., 256, 1180-1184.
Giblett, E. R. (1961). A critique of the theoretical hazard of inter vs. intra-racial transfusion. Transfusion (Philad.), 1, 233-238.

Grobbelaar, B. G., and Smart, E. (1967). The incidence of isosensitization following blood transfusion. Transfusion (Philad.), 7, 152-156.

Kissmeyer-Nielsen, F. (1965). Irregular blood group antibodies in 200,000 individuals. Scand. J. Haemat., 2, 331-342.

Levine, P., Robinson, E., Stroup, M., McGee, R., and Bushnell, L. N. (1956). A summary of atypical antibodies, rare genotypes, and $\mathrm{ABO}$ hemolytic disease encountered in a one year survey, Blood, 11, 1097-1117.

Lockey, E., Cossart, Y., and Gonzalez-Lavin, L. (1973). Serum hepatitis after open-heart surgery. Thorax, 28, 188-190.

Lostumbo, M. M., Holland, P. V., and Schmidt, P. J. (1966). Isoimmunization after multiple transfusions. New Engl. J. Med., 275, 141-144.

Maycock, W. d'A. (1972). Hepatitis in transfusion services. Brit. med. Bull., 28, 163-168.

Mollison, P. L. (1967). Blood Transfusion in Clinical Medicine, 4th ed. Blackwell, Oxford.

Myhre, B. A., Greenwalt, T. J., and Gajewski, M. (1965). Incidence of irregular antibodies occurring in healthy donor sera. Transfusion (Philad.), 5, 350-354.

Perkins, H. A. (1968). Isoantibodies following open heart surgery. Bibl. haemat. (Basel), 29, 831-840.

Polesky, H. F., Smith, R., and Weirich, F. (1969). Positive antiglobulin tests in cardiac surgery patients. Transfusion (Philad.), 9, 43-46.

Pringle, R. C., Ross, C. A. C., and McMichael, S. (1972). Immunoelectro-osmophoresis and complement fixation tests for detection of hepatitis-associated antigen. Med. Lab. Technol., 29, 13-17.

Proskey, V. J., Morrison, G. R., McQuillan, B. P., and Parker, B. M. (1970). Anicteric and icteric hepatitis after open-heart surgery. Gastroenterology, 58, 203-207.

Race, R. R., and Sanger, R. (1968). Blood Groups in Man, 5th ed. Blackwell, Oxford.

Stratton, F. (1953). Detection of weak $\mathrm{Rh}$ antibodies in maternal antenatal sera: the value of enzyme-treated test cells. Lancet, 1, 1169-1172.

Wallace, J. M., and Henry, J. B. (1965). Isoimmunization after massive transfusion for open heart surgery. Transfusion (Philad.), 5, 153-157. 